$28: 596$

\title{
くシンポジウムV V
}

Soluble Flt-1 の虚血後遺伝子導入は血管新生を抑制せず

脳梗塞を縮小する

$\begin{array}{llllll}\text { 熊井 } & \text { 康敬 } & \text { 大星 博明 石川 英一 } & \text { 杉森 宏 } \\ \text { 鴨打 } & \text { 正浩 } & \text { 北園 孝成 井林 雪郎 } & \text { 飯田 三雄 } \\ & & \text { 九州大学大学院医学研究院病態機能内科学 } & & \end{array}$

Key words : アデノウイルス, 遺伝子治療、脳虚血, sFlt-1, VEGF

(脳卒中 28: 596-599, 2006)

\section{はじめに}

脳浮腫は脳梗塞においてしばしば致死的な重大合併 症の一つとなる，血管内皮增殖因子（Vascular endothelial growth factor: VEGF) は虚血脳に強く発現す ることが報告されているが゙，血管新生を促す因子で あると同時に，脳虚血後早期にみられる血管透過性の 充進に強く関与していることが示唆されている。これ までにVEGFの投与によって脳梗塞に対する保護効 果を示した報告が多い22. 一方で, VEGFを抑制する 蛋白の投与によって脳梗塞が縮小することを示した報 告もある゙'。

Soluble Flt-1（sFlt-1）は VEGF1 型受容体 (Flt-1)の 膜貫通部やチロシンキナーゼドメインを持たない可溶 性蛋白であり, VEGF と結合することにより強力な抑 制作用を有する（図 1)，我々は脳浮腫を治療標的とし て、sFlt-1を組み込んだアデノウイルスベタター (AdsFlt-1) を脳虚血後に脳室内に導入し, 虚血 1 日後 の脳梗塞容積と血管透過性, 脳浮腫が抑制されること を既に報告している（第 17 回日本脳循環代謝学会総 会).

今回, sFlt-1 の遺伝子導入を脳虚血後に行い, 虚血 7 日後における脳梗塞容積, 単球/マクロファージの浸 潤，血管新生に及ぼす影響について検討した。

\section{方法}

5〜8 カ月齢の雄性高血压自然発症ラットを用いた. ラットはハロセンで麻醉導入し，大腿動静脈にカテー テルを挿入した．経口指管後, pancronium bromide を用い，人工呼吸器により調節呼吸を行った，ラット

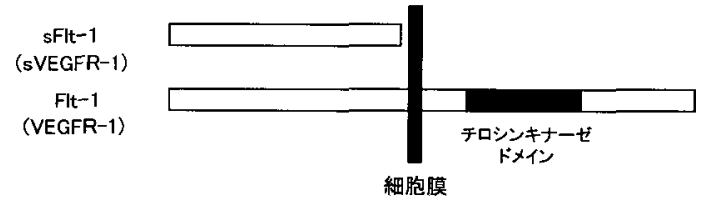

図 1 Soluble Flt-1（sFlt-1）。sFlt-1 は VEGF1 型受容体 (Flt-1) の splicing variant である可溶性蛋白で, VEGF と結合してその作用を抑制する.

は定位固定台に固定し，硬膜を切開することなく遠位 部中大脳動脈を露出した，光感受性色素ローズベンガ ル $(20 \mathrm{mg} / \mathrm{kg})$ を静注し, $568 \mathrm{~nm}, 20 \mathrm{~mW}$ のクリプト ンレーザー(CO-HERENT, innova 300)を 3 分間中大 脳動脈に照射して，血栓性閉塞を作成した，血圧，直 腸温ならびに頭部温度は持続的に, 血液ガス, 血梼, ヘマトクリットは中大脳動脈閉塞前後で測定した，頭 頂葉皮質の脳血流を, 虚血前後で laser Doppler flowmetryにより測定した. 脳虚血 90 分後に AdsFlt-1 $\left(6.8 \times 10^{9}\right.$ plaque forming units $\left.(\mathrm{pfu}) / \mathrm{mL}, \mathrm{n}=9\right)$, あ るいは対照ベクター Ad $\beta$ gal $\left(6.8 \times 10^{9} \mathrm{pfu} / \mathrm{mL}, \mathrm{n}=9\right)$ を $30 \mu l$ 虚血側側脳室内に注入した. 脳虚血 1 または 7 日 後に発現蛋白 (sFlt-1)の定量 (ELISA ; RayBiotech)の ため䚛液を採取した後，脳を灌流固定し， cresyl violet 染色を用いて梗塞容積を測定した，免疫染色により， 梗塞巣における血管床 (von Willebrand factor [vWF] 陽性面皘）と血管新生（vWF-Ki67 二重染色陽性細胞 数)，単球/マクロファージの浸潤（ED1 陽性細胞）を 俨価した。数值は平均佔士標準誤差で表した。 


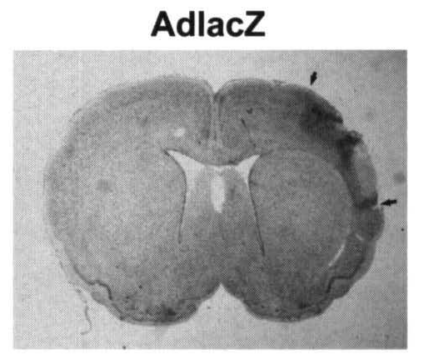

AdsFIt-1

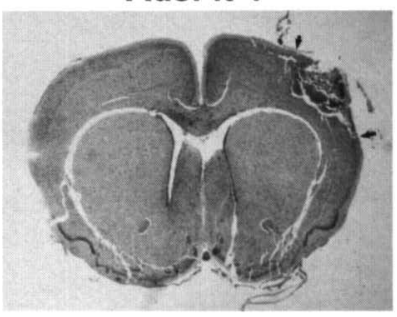

$\left(\mathrm{mm}^{3}\right) \quad$ Day 7 after ischemia

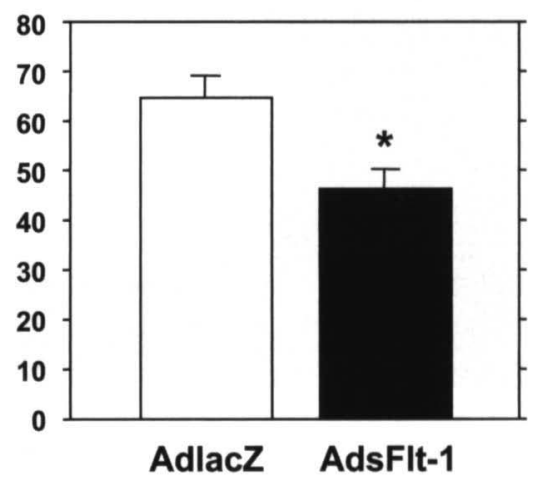

図 2 脳虚血 7 日後の脳梗塞容積. 左図: 矢頭を結ぶ部分が脳梗塞領域 (cresyl violet 染色). 右図 : AdsFlt-1 群の脳梗塞容積は対照群（AdlacZ 群）に比べて有意に減少 していた $(* P<0.01)$.

\section{結 果}

生理学的諸変量は両群間に有意な差はみられなかっ た. 虚血後の脳血流量は虚血前值に比べ対照群で $-66 \pm 2 \%$, AdsFlt-1 群で $-66 \pm 2 \%$ と，両群間に有意 差はなかった. 遺伝子導入 1 日後の AdsFlt-1 群の䯣液 中 sFlt-1 濃度は $1,072 \pm 81 \mathrm{pg} / \mathrm{ml}$ であり, control 群 $(117 \pm 42 \mathrm{pg} / \mathrm{ml})$ と対照群 $(1$ 日後 $134 \pm 43 \mathrm{pg} / \mathrm{ml})$ に 比べて有意に高く, 7 日後でも AdsFlt-1 群 $(225 \pm 26$ $\mathrm{pg} / \mathrm{ml})$ は control 群と対照群 $(7$ 日後 $130 \pm 34 \mathrm{pg} / \mathrm{ml})$ に比べて有意に高く,導入遺伝子発現の持続を認めた。

AdsFlt-1 群の虚血 7 日後の脳梗塞容積 $(40 \pm 4$ $\left.\mathrm{mm}^{3}\right)$ は対照群 $\left(54 \pm 5 \mathrm{~mm}^{3}\right)$ に比べて有意に減少して いた(図 2). AdsFlt-1 群の単球/マクロファージの浸潤 (22,334 $\pm 1,302$ cells $\left./ \mathrm{cm}^{2}\right)$ は対照群 $(30,509 \pm 3,937$ cells/ $\left.\mathrm{cm}^{2}\right)$ に比べ有意に減少していた $(P<0.05)$.

虚血 7 日後, 脳虚血部の血管床は, AdsFlt-1 群 $(0.52 \pm 0.10 \%)$ と対照群 $(0.32 \pm 0.06 \%)$ には有意差を 認めなかった $(P=0.104$, 図 3$)$ ，脳虚血部の血管新生に 関しても，AdsFlt-1 群 $\left(409 \pm 55\right.$ cells $\left./ \mathrm{cm}^{2}\right)$ と対照群 $\left(1,037 \pm 108 \mathrm{cells} / \mathrm{cm}^{2}\right)$ 間に有意差はみられなかった $(P=0.292)$.

\section{考察}

アデノウイルスベクターを用いた sFlt-1 の脳虚血後
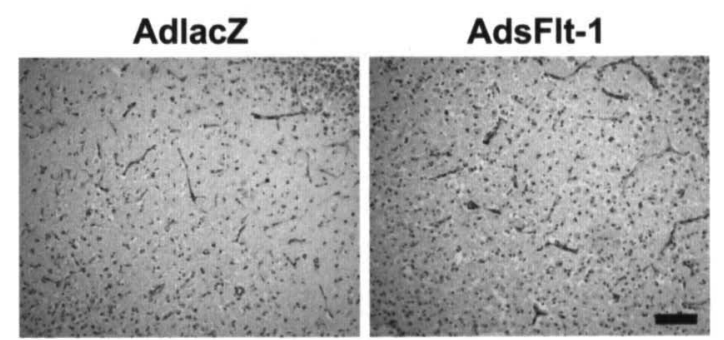

図 3 脳虚血 7 日後の脳梗塞領域における血管床 ( $\mathrm{vWF}$ 染 色). $\mathrm{Bar}=100 \mu \mathrm{m}$.

遺伝子導入は, 脳梗塞巣での単球/マクロファージ浸潤 を抑制し，血管新生を阻害することなく虚血 7 日後の 脳梗塞容積を縮小しており, 脳梗塞の遺伝子治療とし ての有用性が示唆された。

我々は既に $\beta$-galactosidase と変異型 MCP-1 遺伝子 を用いてラット側脳室への遺伝子導入を行い, 導入遺 伝子発現の時間的経過を観察しているが. 導入遺伝子 の発現は導入 6 時間後に認められ， 1 日後をピークと し, 5〜7 日後にかけて徐々に減衰した ${ }^{4}$. 本研究でも, 髄液中の sFlt-1 濃度は導入 1 日後に著明な発現を認 め, 7 日後まで control 群に比べ有意な発現の持続を認 めたが, 遺伝子導入の利点のひとつである単回の投与 でも治療効果を発揮することを支持する成績である. 脳血管障害に対する遺伝子治療では，血管や神経，炎 症への種々の効果が期待されている（図 4)。脳梗塞を 


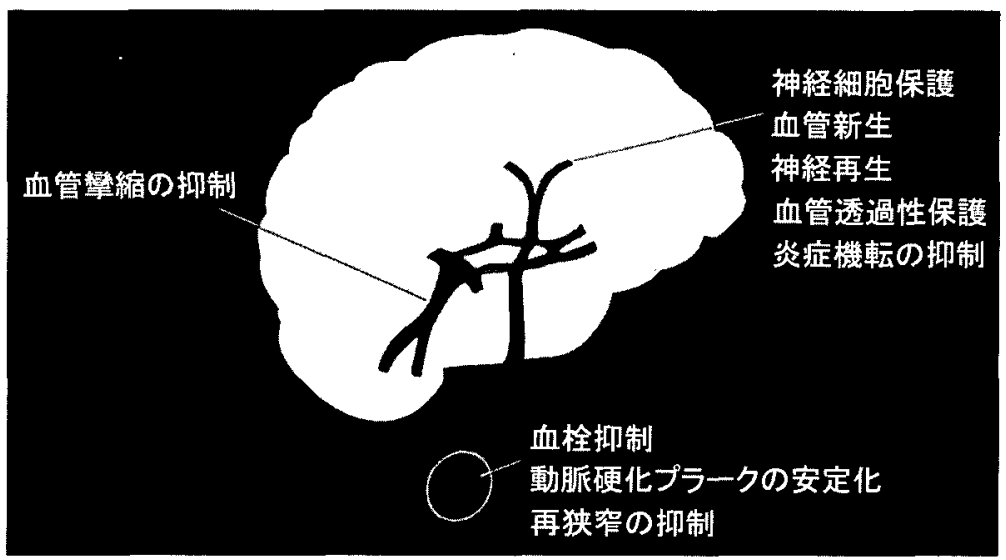

図 4 脳血管障害に対する遺伝子治療の標的，脳血管や神経の病変，炎症機転などに 対して有效性が期待される.

治療標的とした遺伝子導入の投与法には，主に脳組織 と脳槽，脳室内投与があるが，なかでも脳室内への遺 伝子導入は脳室壁に導入遗伝子の著明な発現が得ら れ, 脳梗塞の治療として有望と考えられている5 .

脳梗塞に対するVEGF の有効性はこれまでに報告 されているが, 脳虚血急性期での VEGF 投与には問題 点もある.すなわち，少量の VEGF 投与では脳梗塞に 対して保護効果がみられたが, 高用量の VEGF 投与で は保護効果がみられず，VEGF 投与量の調節が重要で あることが示唆されている6). また，脳虚血 2 日後の VEGF 投与では脳梗塞と血液脳関門破壊を改善させ るのに対して，脳虚血 1 時間後ではむしろ増悪させて いる7). さらに，脳虚血 2 時間後の VEGF 投与によっ て, 梗塞巣血管周囲の出血性変化が増悪するとの報告 もある の投与が血液脳関門破壊を増悪し，結果的に脳梗塞の 増悪をきたす危険性があることを示唆している，脳浮 腫は脳虚血急性期において重要な合併症の一つであ り，VEGFの抑制により脳浮腫が軽減できる可能性が ある，これまでに脳虚血や低酸素脳症に対するVEGF 抑制治療が検討されているが、これらの報告では脳虚 血前に治療を開始することにより，有效性を示唆して いるが3199，今回の我々の検討では脳虚血後に施行した 治療による有効性を示しており，前臨床研究としてよ り意義あるものと考えている。

VEGF は脳の炎症モデルを含む種々の実験モデル で, 単球/マクロファージの遊走を促進することが示さ れている、VEGF1 型受容体は単球/マクロファージに 発現しており, VEGFは単球/マクロファージをコ
ラーゲン膜や内皮を通過して浸潤させる作用があ $3^{(0)}$ ，今回の結果でも， sFlt-1 遺伝子治療が梗塞巣の 単球/マクロファージ浸潤を抑制しており，脳梗塞の縮 小に寄与していると考えられる.

VEGF は血管内皮増殖因子であり，sFlt-1 遺伝子治 療が脳梗塞巣での血管新生を阻害することが懸念され た．しかし，本実験では sFlt-1 遺伝子治療によって虚 血 7 日後の脳梗塞巣での血管新生は阻害されていない ことが認められた．これまでの脳虚血に対するVEGF 抑制療法では，血管新生に関する検討がなされていな いが, 脳虚血に対するVEGF 投与療法では血管新生に ついて検討されている，VEGFの投与法には経静脈， 経動脈，経脳室などがあるが，いずれの投与法によっ ても血管新生は改善しており，投与法による違いは血 管新生に関係がないように思われる.脳虚血1日もし くは2 日後の VEGF 投与では血管新生が促され，さら に神経機能障害に対する有效性も示されている7》．血 管新生に対する sFlt-1 遺伝子治療の効果については更 なる研究が必要であるが，本害験で sFlt-1 遺伝子治療 により血管新生が阻害されなかったことは脳梗塞の縮 小効果に好影響を与えていると考えられた。

\section{結語}

脳虚血超急性期での sFlt-1 遺伝子治療は虚血 7 日後 の脳梗塞を縮小させた. sFlt-1 遺伝子治療は単球/マク ロファージ浸潤を抑制し，かつ血管新生を阻害してい ないことは，脳梗塞を縮小させることに寄与している と考えられた，したがって, sFlt-1 遺伝子治療は，脳虚 血に対する治療とし有望である可能性が示された。 


\section{謝辞}

本研究の一部は平成 17 年 21 世紀 COE 若手研究者研究 活動経費によった.

\section{文献}

1) Hayashi T, Abe K. Suzuki H, et al. : Rapid induction of vascular endothelial growth factor gene expression after transient middle cerebral artery occlusion in rat. Stroke $28: 2039-2044,1997$

2) Hayashi $T$, Abe K, Itoyama $Y$. : Reduction of ischemic damage by application of vascular endothelial growth factor in rat brain after transient ischemia. J Cereb Blood Flow Metab 18:887895,1998

3) van Bruggen $N$, Thibodeaux H, Palmer JT, et al. : VEGF antagonism reduces edema formation and tissue damage after ischemia/reperfusion injury in the mouse brain. J Clin Invest 104: 1613-1620, 1999

4) Kumai Y, Ooboshi H, Takada J. et al. : M Antimonocyte chemoattractant protein-1 gene therapy protects against focal brain ischemia in hypertensive rats. J Cereb Blood Flow Metab 24 : $1359-1368,2004$

5) Ooboshi H, Ibayashi S, Shichita T. et al.: Postischemic gene transfer of interleukin-10 pro- tects against both focal and global brain ischemia. Circulation $111: 913-919,2005$

6) Manoonkitiwongsa PS, Schultz RL, McCreery DB. et al. : Neuroprotection of ischemic brain by vascular endothelial growth factor is critically dependent on proper dosage and may be compromised by angiogenesis. J Cereb Blood Flow Metab $24: 693-702,2004$

7) Zhang ZG, Zhang L, Jiang Q. et al. : VEGF enhances angiogenesis and promotes blood-brain barrier leakage in the ischemic brain. J Clin Invest $106: 829-838,2000$

8) Abumiya T, Yokota C, Kuge Y. et al. : Aggravation of hemorrhagic transformation by early intraarterial infusion of low-dose vascular endothelial growth factor after transient focal cerebral ischemia in rats. Brain Res 1049:95-103, 2005

9) Schoch HJ, Fischer S, Marti HH. : Hypoxiainduced vascular endothelial growth factor expression causes vascular leakage in the brain. Brain 125:2549-2557,2002

10) Clauss M, Gerlach M, Gerlach H. et al. : Vascular permeability factor : a tumor-derived polypeptide that induces endothelial cell and monocyte procoagulant activity, and promotes monocyte migration. J Exp Med $172: 1535-1545,1990$

\title{
Abstract \\ Postischemic gene transfer of soluble Flt-1 protects against brain ischemia without inhibiting angiogenesis
}

\author{
Yasuhiro Kumai, M.D., Hiroaki Oboshi, M.D., Ph.D. Eiichi Ishikawa, M.D., Hiroshi Sugimori, M.D., Ph.D. \\ Masahiro Kamouchi, M.D., Ph.D. Takanari Kitazono, M.D., Ph.D. \\ Setsuro Ibayashi, M.D. Ph.D. and Mitsuo Iida, M.D. Ph.D.
}

Department of medicine and clinical science, Graduate school of medical science, Kyushu university

Brain edema is a major and often mortal complication of brain ischemia. Vascular endothelial growth factor (VEGF) is also known as a potent vascular permeability factor and may play detrimental roles at the acute stage of brain infarction. We explored protective effects of gene transfer of soluble flt- 1 (sFlt-1), a natural inhibitor of VEGF, on focal brain ischemia. Adenoviral vectors encoding sFlt-1 or $\beta$-galactosidase were injected into the lateral ventricle 90 minutes after photochemical distal middle cerebral artery occlusion in male spontaneously hypertensive rats. The transduced sFlt-1 was released into the cerebrospinal fluid from the ventricular wall and significantly increased 1 and 7 days after sFlt-1 transfection. Seven days after ischemia, sFlt1 gene transfer significantly attenuated infarct volume (by 29\%) and monocyte/macrophage infiltration (by $27 \%$ ) although there were no reductions in angiogenesis by sFlt-1 overexpression. These results suggest that sFlt-1 gene therapy targeting brain edema in acute stage of brain ischemia may be usefulness for brain infarction.

(Jpn J Stroke 28:596-599, 2006)

Key words : adenovirus, brain ischemia, gene therapy, sFlt-1, VEGF 